\title{
Data on the Changes Occurring in the Biosphere Since 1778
}

\author{
Béla Ralovich \\ Ministry of Welfare, Budapest, Hungary (Retired) \\ Email: ralovich.bela@freemail.hu
}

Received 2 March 2016; accepted 24 May 2016; published 27 May 2016

Copyright (C) 2016 by author and Scientific Research Publishing Inc.

This work is licensed under the Creative Commons Attribution International License (CC BY).

http://creativecommons.org/licenses/by/4.0/

(c) (i) Open Access

\begin{abstract}
In our previous publications, we dealt with some general questions connected with biological life and its conditions, the Biosphere as a "closed system" and in our latest paper with the different periods of the Earth's existence (Ralovich Béla), [1]-[6]. In the present article, we show one part of the processes and changes that occurred in our environment during the last 165 years. Performing of our work was difficult because some of the data required are missing and those which were published in single papers frequently differed from each other. It is also a problem that we are neither mathematicians nor physicists. Despite these difficulties, we hope that our efforts will not be fruitless.
\end{abstract}

Keywords

Biosphere, Closed System, Demands for Life, Metabolism, Balance of Energy and Substance

\section{Relationships needed to understand the data of this article}

Units of measurement and their notation: exa $-\mathrm{E}=$ quintillion $10^{18}$; peta $-\mathrm{P}=$ quadrillion $10^{15}$; tera $-\mathrm{T}=$ trillion $10^{12}$; giga $-\mathrm{G}=$ billion $10^{9}$; mega $-\mathrm{M}=$ million $10^{6}$; kilo $-\mathrm{k}=$ thousand $10^{3}$.

Relationships: $1 \mathrm{kcal} / \mathrm{h}=1.16 \mathrm{~W}=4.185 \mathrm{~kJ} ; 1 \mathrm{~W}=1 \mathrm{~J} / \mathrm{s} ; 1 \mathrm{Wh}=3600 \mathrm{~J} ; 1 \mathrm{kWh}=3.6 \times 106 \mathrm{~J}$ or $3.6 \mathrm{MJ} ; 1$ $\mathrm{MJ} / \mathrm{kg}=1000 \mathrm{~kJ} / \mathrm{kg} ; 1 \mathrm{MJ}=0.27778 \mathrm{kWh}$;

$R Q$ (respiratory quotient) $=\mathrm{CO}_{2} / \mathrm{O}_{2}$ - when carbohydrates are burnt: 1 ; when lipids: 0.7 ; when proteins: 0.8 0.9 and in case of a mixed diet: c., 0.83 . The use of 1 litre of oxygen in the body results in $4.5-5$ kcal energy depending on the composition of the diet.

In our calculations, 1 cubic metre of $\mathrm{CO}_{2}$ is $1.98 \mathrm{~kg}$ and that value for natural gas is $0.69 \mathrm{~kg}$.

The quantity of $\mathrm{CO}_{2}$ released from one $\mathrm{kg}$ of fuel is regarded to be $2.3 \mathrm{~kg}$ from coal, $3.17 \mathrm{~kg}$ from oil and 2.8 
kg from natural gas.

\section{Characteristic Data of the Sun}

It is evident for everybody that almost all events and energy on our Globe originate from the Sun except that arriving from outside our solar system. According to Simonyi Károly [7], the Sun emits $3.86 \times 10^{33} \mathrm{erg} / \mathrm{s}$ energy, that is, $3.86 \times 10^{23} \mathrm{~kW}$. There is general consensus that the amount of solar energy reaching the Earth apart from minor fluctuations can be considered to be the same. Solar energy when it arrives at right angles to the external surface of the Earth's atmosphere is $1.36 \mathrm{~kW} / \mathrm{m}^{2}$. Solar rays are partly reflected from the atmosphere, the rest is absorbed by the clouds, surface waters and continents. In our terminology the latter two are the so called heat capacity of our Globe. In an ideal case on the Earth's surface c. $1 \mathrm{~kW} / \mathrm{m}^{2}$ heat can be measured, which is equal to $1 \mathrm{~kJ} / \mathrm{s}$. This value is the so called solar constant. Regarding the whole surface of the Globe we estimate the value of this constant to be c. $510,100,000 \times 365 \times 24 \times 3600 \times 1,000,000 \mathrm{~kJ} / \mathrm{m}^{2}$ per year, that is, $\mathbf{1 . 6} \times \mathbf{1 0}^{\mathbf{2 1}}$ $\mathrm{kW} / \mathrm{m}^{2}$. According to another author 126,000 TW energy reaches the Earth's surface and the same amount is radiated. It was also calculated that c. $23 \%$ of the total solar energy arriving at our Globe maintains the water cycle and $1 \%$ to $3 \%$ of it keeps up winds. The quantity of the latter energy is considered to be 50 to 100 times greater than that energy which is used yearly by all the plants on the Earth by photosynthesis, which value is estimated to be $3 \times 10^{21} \mathrm{~J}$.

\section{Characterization of the "Recipient" Earth}

As it was described in our previous articles the Earth lives its own life in the Universe and one component of it is the Biosphere, which is the terrain for biological life and which is a "closed system" for that life. To characterize the Earth and judge its condition, it is necessary to repeat a few of its characteristic data: Surface: $5.101 \times$ $\mathbf{1 0}^{\mathbf{8}} \mathrm{km}^{2}$ or $\mathbf{5 . 1 0 1} \times \mathbf{1 0 ^ { 1 0 }}$ ha; from this: Continents: $29.2 \%=\mathbf{1 . 4 8 9 4 9} \times \mathbf{1 0}^{\mathbf{1 0}}$ ha. $59.4 \%=\mathbf{0 . 8 8 4} \times \mathbf{1 0}^{\mathbf{1 0}}$ ha of the continents are on the Northern hemisphere $\left(2.55 \times \mathbf{1 0}^{\mathbf{1 0}}\right.$ ha), $40.6 \%=\mathbf{0 . 6 0 5} \times \mathbf{1 0}^{\mathbf{1 0}}$ ha of the continents are on the Southern hemisphere $\left(2.55 \times \mathbf{1 0}^{\mathbf{1 0}}\right.$ ha). Forests: in 18825.5 billion ha, in 20054.0 billion ha. Settlements: territory of cities about $2 \%$ of the continents. The territory of the smaller places is unknown. Waters: $70.8 \%=$ $3.611 \times \mathbf{1 0}^{10}$ ha. From this: sea $97 \%-98 \%$, fresh water $2 \%-3 \%$, from which: $10 \%$ surface water, $70 \%$ snow and ice and $20 \%$ underground water.

The quantities of gases in the Atmosphere (steam, $\mathrm{CO}_{2}$, methane*, $\mathrm{CFC}, \mathrm{N}$-oxides, S-oxides and so on) have changed time to time. Average concentration of $\mathrm{CO}_{2}$ in ppm: 1750:250; 1957:315; 1987:350; 2015:403. Over the Northern hemisphere 500! Average concentration of methane in ppb: 1700:1000; 1986:1700*. Average temperature near the surface: $1905: 13.6^{\circ} \mathrm{C} ; 1960: 14.6^{\circ} \mathrm{C} ; 2014: \geq 14.8^{\circ} \mathrm{C}$. Melting of snow and ice: is general, but more important on the Northern hemisphere.

Note $^{*}=$ According to some authors $15 \%-25 \%$ of the methane that can be measured in the atmosphere originates from animals. They state that $74 \%$ of the methane of animal origin is emitted by oxen, $9 \%$ by sheep and $5 \%$ by buffaloes but some small amount of methane is also produced in the bowels of pigs and poultry. These authors did not mention either the role of wild animals or the methane which was produced by different environmental microbes. They stated that the rest of the methane in the atmosphere was produced by human activities but they did not explain what did mean by "activity". If the glass-house effect of $\mathrm{CO}_{2}$ is one unit then that of methane is 21 times greater and that of $\mathrm{N}_{2} \mathrm{O}$ is 310 times bigger. However, some of the authors have thought that the effect of water vapour is the greatest. Incidentally, the phenomenon of the glass-house effect was described by Fourier in 1824 and the related calculations were done by Arrhenius in 1896.).

\section{4. "Heat Capacity" of the Globe}

The different natural and artificial formations and constructions found on the surface of the Earth have different heat capacities. Consequently, every significant change of the surface may result in an alteration of the surface temperature of a given territory or depending on the size of the affected surface even that of the whole Globe. The extent of the changes is determined by the modification of the quantity or size of the following formations and constructions: salt water/fresh water (their effect is influenced by their trophic states), snow and ice fields, forests, shrubs, meadows, areas under agricultural cultivation, deserts, rocky areas, human settlements (in the case of which the following factors have importance: area; size, material and number of buildings; the number of inhabitants; roads, airports, railroads, etc.). 


\section{Effects of Existance of Man Kind and Farm Animals on the Closed Biosphere}

In the following, only the effects of humans and of certain farm animals will be discussed as there are no exact data available on the summarized activity of the innumerable microorganisms or on the number, needs and effects of plants and animals living in the wild. Firstly, it is necessary to determine the differences between human beings and animals. We think that specifically human characteristics are:

- Discovery of the significance of fire and its conscious use.

- Domestication and breeding of animals with an alimentary purpose as well as using of their physical force and nowadays this activity is supplemented by keeping pet animals.

- Cultivation, propagation and improvement of plants for human consumption and feeding of animals as well as for other practical uses.

- "Conscious" use of the powers of nature, such as the energy of the sun, wind, water, atomic reaction and so on. According to our present knowledge there are not living beings on the Earth apart from humans in the activity of which even in the seeds of these characteristics could be detected. On the basis of these characteristics we have thought in our earlier publications that after the appearance of the biological life on the Earth the second decisive change has started on it in consequence of the appearance and activities of conscious human beings (Ralovich Béla [2]-[6]).

In the next part of our text we shall present some data which show the changes of the number of man kind and that of farm animals as well as the metabolic and environmental consequences of their life.

When the first men appeared the surface of the Globe was natural. Since that time the number of individuals has, in essence, constantly increased even, if it underwent dramatic fluctuations in certain time periods. Now we shall deal with only the events of the past 165 years. The following data represent the estimated number of individuals in a given year in billions: 1850:1.17; 1937:2.1; 1950:2.5; 1980:4.4; 2014: c. 7.5. Everybody can realize the significant increase. It should be added to that fact that recently the majority of people live on the northern hemisphere and their housing conditions have changed radically.

It is obvious that primarily human beings lived in small groups. Their places of residence were less permanent (in the fishing, hunting, gathering and later in the herding periods). The increase in the number and needs of men, as well as the changes in their way of life (in consequence of the spread of land cultivation) resulted in the development of permanent settlements with all related communal problems. Although cities and even city-states already existed in ancient times, urbanization was a slow process until the industrial revolution. The development of agriculture, trade, transport, mining and industry facilitated the formation of cities. The process of urbanization started to speed up in Europe in the $18^{\text {th }}$ century, while in the other continents in the $19^{\text {th }}$ and $20^{\text {th }}$ centuries depending on the circumstances. It is still in progress today in many places in a rather explosive form. In 2003 there were 409 cities/agglomerations in which the number of inhabitants was over one million, that is, altogether more than 1.15 billion people resided in these cities using up over $70 \%$ of the total resources of our Globe. At present, over 50\% of the Earth's inhabitants live in cities, however, their ratio varies in individual countries. The physical effects of settlements, especially that of cities are very different from the natural environment, therefore they have caused degrading effects on it. (The heat requirements, size and comfort level of present accommodations as well as the heat adsorption and heat emission of big buildings and wide asphalt/ concrete roads differ from that of the old type small buildings, minor roads and mainly from the green nature. Air, noise, light, heat and communal pollution have all increased. Cities have a so-called “desert climate”. Here we do not deal with the effects of industry and agriculture.)

Using the data of Mike Gyula [8] and Szabó Lajos [9] the changes in the numbers of various farm animals are presented in Table 1 and Table 2. With the exception of horses the number of all farm animals has increased significantly. It should be emphasized that the technologies used in animal husbandry have also undergone important changes during the past 165 years. The ratio of natural extensive animal farming has decreased, while intensive industrial livestock production, so called "animal factory" practice has become dominant almost all over the world together with its serious environmental consequences.

But let us see what the data show. Data of the metabolic requirements as well as the emitted materials and heat of humans and animals are presented in Table 3, Table 4(a) and Table 4(b).

The values of a single person and one farm animal as well as that of man kind and all farm animals (which are presented in Table 3. and Table 4(a)) are calculated in an integrated form both at rest and in the case of an average daily activity level. Data related to gender, age, weight, activity, life cycle and any other factors which can 
Table 1. Changing of the number of domestic animals during the last decades.

\begin{tabular}{cccccc}
\hline Specifications & \multicolumn{5}{c}{ Animal Species and Numbers $\times 10^{6}$} \\
\hline Years & Oxen & Horses & Pigs & Sheep & Hens \\
\hline 1930 -ies & 438.9 & 68.1 & 193.3 & 563 & a.n. \\
$1999-2000$ & 1351.4 & 58.2 & 922.8 & 1056.1 & 14,860 \\
\hline
\end{tabular}

Abbreviation: a.n. = datum is unknown.

Table 2. Number of other farm animals.

\begin{tabular}{cccccc}
\hline Specifications & \multicolumn{5}{c}{ Species of Domestic Animals and Their Numbers $\times 10^{6}$} \\
\hline Continents & Goats & Buffalos & Donkeys* & Camels & Llamas** \\
\hline Europe & 17.9 & 0.2 & 0.8 & - & - \\
Asia & 465.2 & 160.9 & 18.8 & 4.2 & - \\
Africa & 218.6 & 3.4 & 15.4 & $7.8^{* * * *}$ & - \\
N., C. and S. America & 35.8 & 1.1 & - & - & $5.3^{* * *}$ \\
Oceania & 0.7 & - & 42.8 & 19.3 & - \\
World Total & 738.2 & 165.6 & 5.3 \\
\hline
\end{tabular}

Abbreviations: * = donkey and mule together; ** = llama, alpaca, vicuna and guanaco together; *** = only S. American data; **** = only C. American data; - = no datum.

influence the values were not taken into account because they are missing. We were encouraged to follow this solution as the results of our check calculations did not show significant alterations. Let us consider for example $\mathrm{CO}_{2}$ emissions. In the calculation the average human values accepted in the literature are used, but the data which are presented in our Table 3 would have been used as well. Based on the accepted values an average of $480 \mathrm{l}$ of $\mathrm{CO}_{2}$ per day is emitted at rest. During normal everyday activities this value is $1440-3120 \mathrm{l} /$ day, while during strenuous exercise it is $7920-9120 \mathrm{l} /$ day. The annual values calculated on the basis of the accepted numbers are the following: $1.75 \times 10^{5} ; 5.25 \times 10^{5}-1.13 \times 10^{6}$ and $2.89 \times 10^{6}-3.32 \times 10^{6}$ l/year. Based on a daily rhythm of eight hours of rest and sixteen hours of normal daily activity the result of the calculations is $6.13 \times$ $10^{5} \mathrm{l} /$ day, that is, the difference is only of one order of magnitude, which is acceptable.

As to the requirements and emissions of farm animals, they can be found in Table 4(a) and Table 4(b). Exact datum on the amount of $\mathrm{O}_{2}$ consumed and $\mathrm{CO}_{2}$ emitted by a calf was found in a single animal experiment only. Some data on water need, quantity of urine and faeces, the methane emission, evaporation and perspiration were found. We know only one source as to water use for technological purposes and also the quantity of sewage water. Although heat emission by expiration and panting is remarkable in certain species we were not able to get measured data (Bárdos László et al. [10], Boadi Dinah et al. [11], Breazile J. E. [12], Clark Jeremy Austin [13], Ruckebusch Yves et al. [14], Sjaastad Ø ystein. V. et al. [15]).

We performed the calculations in case of farm animals on the same simplified way as it was done in case of humans as not all animal data were available and also because the values obtained are suitable to demonstrate the gravity of the problems. The validity of our supposition is demonstrated by the energetic data of a calf weighing $75 \mathrm{~kg}$ and a cow weighing $600 \mathrm{~kg}$ as shown in Table 4(a). While in case of the calf the daily value was $7713 \mathrm{~kJ}$ and the annual one was $\mathbf{2 . 8 1} \times \mathbf{1 0}^{\mathbf{6}} \mathrm{kJ}$ the values measured for the cow were 35,572 and $\mathbf{1 . 2 9} \times \mathbf{1 0}^{\mathbf{7}}$ $\mathrm{kJ}$. If the requirements of the 1,350,400,000 cows were calculated based on the data for calves the annual value arrived at was $3.79 \times \mathbf{1 0}^{15} \mathrm{~kJ}$, while using the cows' "own" values in the calculations the result was $1.74 \times 10^{\mathbf{1 6}}$ $\mathrm{kJ}$. That is, the difference is "only" of one order of magnitude which is an acceptable difference in the present case. As it will be apparent later we observed a similar problem when calculating the amount of energy and carbon dioxide liberated during burning for example natural gases of differing qualities and calorific values.

The data which are presented in Table 3, Table 4(a) and Table 4(b) give much food for thought. At present the number of people and domestic animals is so large that great amounts of life-sustaining materials are needed and the amount of metabolic products emitted into the environment including heat is also considerable. To understand the total problem of environmental pollution the data presented should be complemented by the needs and effects of the innumerably huge number of microorganisms and of the other cold- and warm-blooded 
Table 3. Supposed life demands and emissions of a person and of the man kind.

\begin{tabular}{|c|c|c|c|c|}
\hline \multirow{2}{*}{$\begin{array}{c}\text { Specifications } \\
\text { Demands }\end{array}$} & \multicolumn{2}{|c|}{ One Person } & \multicolumn{2}{|c|}{ Man Kind (7.5 × $10^{9}$ persons $)$} \\
\hline & Basic Metabolism & Everyday Life & Basic Metabolism & Everyday Life \\
\hline \multicolumn{5}{|l|}{ Oxygen } \\
\hline 1/day & 360 & 1000 & $2.70 \times 10^{12}$ & $7.5 \times 10^{12}$ \\
\hline 1/year & $1.31 \times 10^{5}$ & $3.65 \times 10^{5}$ & $9.85 \times 10^{14}$ & $2.73 \times 10^{15}$ \\
\hline \multicolumn{5}{|l|}{ Energy (Sex Dependent) } \\
\hline MJ/day & $6.27-7.95$ & 9.96 & $4.68-5.94 \times 10^{10}$ & $7.44 \times 10^{11}$ \\
\hline MJ/year & $2293.3-2904.3$ & 3636.7 & $1.72-2.17 \times 10^{13}$ & $2.81 \times 10^{14}$ \\
\hline \multicolumn{5}{|l|}{ Metabolism } \\
\hline W/day & 88 & 243 & $6.60 \times 10^{11}$ & $1.82 \times 10^{12}$ \\
\hline W/year & $3.2 \times 10^{4}$ & $8.87 \times 10^{4}$ & $2.74 \times 10^{12}$ & $6.65 \times 10^{14}$ \\
\hline \multicolumn{5}{|l|}{ Drinking Water } \\
\hline 1/day & - & $2-2.5$ & - & $1.50-1.88 \times 10^{10}$ \\
\hline 1/year & - & $730-913$ & - & $5.48-6.84 \times 10^{12}$ \\
\hline \multicolumn{5}{|l|}{ General Water Use } \\
\hline 1/day & - & 50 & - & $3.75 \times 10^{11}$ \\
\hline 1/year & - & $1.83 \times 10^{4}$ & - & $1.37 \times 10^{14}$ \\
\hline \multicolumn{5}{|l|}{ Protein } \\
\hline g/day & - & 50 & - & $3.75 \times 10^{11}$ \\
\hline $\mathrm{kg} /$ year & - & 18.3 & - & $1.37 \times 10^{14}$ \\
\hline \multicolumn{5}{|l|}{ Emissions } \\
\hline \multicolumn{5}{|l|}{$\mathrm{CO}_{2}$ in Case of the $\mathrm{O}_{2}$ Demand Presented } \\
\hline l/day & *270 & *750 & $* 2.03 \times 10^{12}$ & $* 5.63 \times 10^{12}$ \\
\hline l/year & $* 9.86 \times 10^{4}$ & $* 2.74 \times 10^{5}$ & $* 7.39 \times 10^{14}$ & $* 2.05 \times 10^{15}$ \\
\hline \multicolumn{5}{|l|}{ Heat $25 \%$ of the Metabolism } \\
\hline W/day & 22 & 60.75 & $2.57 \times 10^{16}$ & $4.55 \times 10^{10}$ \\
\hline W/year & $8.03 \times 10^{3}$ & $2.21 \times 10^{4}$ & $6.02 \times 10^{13}$ & $1.66 \times 10^{14}$ \\
\hline Water (Expiration, Evaporation) & - & - & - & - \\
\hline \multicolumn{5}{|l|}{ Urine } \\
\hline 1/day & - & 1.5 & - & $1.13 \times 10^{10}$ \\
\hline 1/year & - & 547.5 & - & $4.11 \times 10^{12}$ \\
\hline \multicolumn{5}{|l|}{ Faeces } \\
\hline g/day & - & $100-500$ & - & $7.50 \times 10^{11}-3.75 \times 10^{12}$ \\
\hline $\mathrm{kg} /$ year & - & $36.5-182.5$ & - & $2.74 \times 10^{11}-1.37 \times 10^{12}$ \\
\hline \multicolumn{5}{|l|}{ Sewage } \\
\hline $\begin{array}{c}\text { l/day } \\
\mathrm{m}^{3} / \text { year }\end{array}$ & \multicolumn{2}{|c|}{ Proportional to the water used } & \multicolumn{2}{|c|}{ Proportional to the water used } \\
\hline \multicolumn{5}{|l|}{ Solid Communal Wastes** } \\
\hline $\mathrm{m}^{3} /$ day & - & $0.00164-0.00329$ & - & $1.23-2.47 \times 10^{7}$ \\
\hline $\mathrm{m}^{3} /$ year & - & $0.6-1.2$ & - & $4.50-9.0 \times 10^{9}$ \\
\hline t/year & - & $\approx 0.4$ & - & $\approx 3 \times 10^{9}$ \\
\hline
\end{tabular}

Abbreviations: - = no datum; * = Calculated with the RQ. Its value is $0.83 ; * *=$ Hungarian data. 
Table 4. (a) Living conditions of different farm animals. (b) Emissions of different species of farm animals.

(a)

\begin{tabular}{|c|c|c|c|c|c|c|c|c|c|c|}
\hline \multirow{3}{*}{$\begin{array}{c}\text { Specification } \\
\text { Demands }\end{array}$} & \multicolumn{10}{|c|}{ Species of Animals and Their Numbers $\times$ Million } \\
\hline & \multicolumn{2}{|c|}{ Oxen } & \multicolumn{2}{|c|}{ Horses } & \multicolumn{2}{|c|}{ Pigs } & \multicolumn{2}{|c|}{ Sheep } & \multicolumn{2}{|c|}{ Hens } \\
\hline & $\begin{array}{c}1 \\
\text { Animal }\end{array}$ & 1351.4 & $\begin{array}{c}1 \\
\text { Animal }\end{array}$ & 58.2 & $\begin{array}{c}1 \\
\text { Animal }\end{array}$ & 922.8 & $\begin{array}{c}1 \\
\text { Animal }\end{array}$ & 1056.1 & $\begin{array}{c}1 \\
\text { Animal }\end{array}$ & 14,860 \\
\hline \multicolumn{11}{|l|}{$\mathrm{O} 2$} \\
\hline$*^{*}$ calf l/day & 390 & $5.27 \times 10^{11}$ & a.n. & a.n. & a.n. & a.n. & a.n. & a.n. & a.n. & a.n. \\
\hline *calf 1/year & $1.42 \times 10^{5}$ & $1.92 \times 10^{14}$ & a.n. & a.n. & a.n. & a.n. & a.n. & a.n. & a.n. & a.n. \\
\hline Energy & & & & & & & & & & \\
\hline $\mathrm{kJ}(\mathrm{kcal}) \times \mathrm{kg}^{0.75}$ daily & \multicolumn{10}{|c|}{ Basic metabolism of all animals 293 (70) } \\
\hline yearly & \multicolumn{10}{|c|}{$1.07 \times 10^{5}\left(2.55 \times 10^{4}\right)$} \\
\hline $\begin{array}{l}\mathrm{kJ} \times \mathrm{kg}^{0.75} \\
\text { daily }\end{array}$ & \multicolumn{10}{|c|}{$\begin{array}{l}\text { Fasting metabolism of all animals } \\
\qquad 475 \text { - } 575 \text { average: } 525\end{array}$} \\
\hline yearly & \multicolumn{10}{|c|}{$1.91 \times 10^{5}$} \\
\hline$*_{\text {calf daily } \mathrm{kJ}}$ & $7.71 \times 10^{3}$ & $1.04 \times 10^{13}$ & - & - & - & - & - & - & - & - \\
\hline yearly kJ & $2.81 \times 10^{6}$ & $3.80 \times 10^{15}$ & - & - & - & - & - & - & - & - \\
\hline $\begin{array}{l}\left(\mathrm{kg}^{* *}\right) \\
\mathrm{kJ} \text { daily }\end{array}$ & $\begin{array}{c}(600) \\
3.55 \times 10^{4}\end{array}$ & $4.77 \times 10^{13}$ & $\begin{array}{c}(500) \\
3.09 \times 10^{4}\end{array}$ & - & $\begin{array}{l}(100) \\
9207\end{array}$ & - & $\begin{array}{l}(50) \\
5440\end{array}$ & - & $\begin{array}{l}(2) \\
502\end{array}$ & - \\
\hline yearly & $1.29 \times 10^{7}$ & $1.75 \times 10^{16}$ & $1.12 \times 10^{7}$ & - & $3.36 \times 10^{6}$ & - & $1.98 \times 10^{6}$ & - & $1.8 \times 10^{5}$ & - \\
\hline \multicolumn{11}{|l|}{ Metabolism } \\
\hline $\begin{array}{l}\left(\mathrm{kg}^{* *}\right) \\
\text { W/day }\end{array}$ & $\begin{array}{c}(600) \\
411\end{array}$ & - & $\begin{array}{c}(500) \\
358\end{array}$ & - & $\begin{array}{c}(100) \\
106\end{array}$ & - & $\begin{array}{l}(50) \\
62.9\end{array}$ & - & $\begin{array}{l}(2) \\
5.8\end{array}$ & - \\
\hline W/year & $1.5 \times 10^{5}$ & - & $1.30 \times 10^{5}$ & - & $3.88 \times 10^{4}$ & - & $2.29 \times 10^{4}$ & - & $2.11 \times 10^{3}$ & - \\
\hline * calf W/day & 89.16 & - & - & - & - & - & - & - & - & - \\
\hline * calf W/year & $3.25 \times 10^{4}$ & - & - & - & - & - & - & - & - & - \\
\hline \multicolumn{11}{|l|}{ Drinking water } \\
\hline $\mathrm{ml} / \mathrm{kg}$ & 129 & - & 78 & - & 108 & - & 76 & - & a.n. & a.n. \\
\hline $\begin{array}{l}\left(\mathrm{kg}^{* *}\right) \\
\mathrm{l} / \text { day }\end{array}$ & $\begin{array}{c}(600) \\
77.4\end{array}$ & - & $\begin{array}{c}(500) \\
39\end{array}$ & - & $\begin{array}{c}(100) \\
10.8\end{array}$ & - & $\begin{array}{c}(50) \\
3.8\end{array}$ & - & $0.25 * * *$ & - \\
\hline 1/year & $2.82 \times 10^{4}$ & - & $1.42 \times 10^{4}$ & - & $3.94 \times 10^{3}$ & - & $1.38 \times 10^{3}$ & - & $73-110$ & - \\
\hline \multicolumn{11}{|c|}{ Technological water } \\
\hline l/day & a.n. & a.n. & a.n. & a.n. & 15 & - & a.n. & a.n. & a.n. & a.n. \\
\hline 1/year & a.n. & a.n. & a.n. & a.n. & $5.47 \times 10^{3}$ & - & a.n. & a.n. & a.n. & a.n. \\
\hline
\end{tabular}

Abbreviations: $*$ = experimental datum of one calf of $75 \mathrm{~kg} ;(* *)=$ body mass; $* * *=$ in case of one animal; a.n. = datum is unknown; - = no datum.

(b)

\begin{tabular}{|c|c|c|c|c|c|c|c|c|c|c|}
\hline \multirow{3}{*}{$\begin{array}{c}\text { Specifications } \\
\text { Emissions }\end{array}$} & \multicolumn{10}{|c|}{ Species of Animals and Their Number $\times$ Million } \\
\hline & \multicolumn{2}{|c|}{ Oxen } & \multicolumn{2}{|c|}{ Horses } & \multicolumn{2}{|c|}{ Pigs } & \multicolumn{2}{|c|}{ Sheep } & \multicolumn{2}{|c|}{ Hens } \\
\hline & 1 & 1351.4 & 1 & 58.2 & 1 & 922.8 & 1 & 1056.1 & 1 & 14,860 \\
\hline \multicolumn{11}{|l|}{$\begin{array}{c}\mathrm{CO}_{2} \text { in case of } \mathrm{O}_{2} \\
\text { presented }\end{array}$} \\
\hline${ }^{*}$ calf l/day & 311 & $4.2 \times 10^{11}$ & a.n. & a.n. & a.n. & a.n. & a.n. & a.n. & a.n. & a.n. \\
\hline *calf 1/year & $1.13 \times 10^{5}$ & $1.53 \times 10^{14}$ & a.n. & a.n. & a.n. & a.n. & a.n. & a.n. & a.n. & a.n. \\
\hline \multicolumn{11}{|l|}{ Methane } \\
\hline 1/day & $100-500$ & $\begin{array}{c}1.35- \\
6.75 \times 10^{11}\end{array}$ & - & - & $0.3-1.5$ & $\begin{array}{c}2.7- \\
13.8 \times 10^{8}\end{array}$ & $<50$ & $\begin{array}{c}>5.3 \times \\
10^{10}\end{array}$ & - & - \\
\hline 1/year & $\begin{array}{c}3.65- \\
18.2 \times \\
10^{4}\end{array}$ & $\begin{array}{c}4.94- \\
2466 \times \\
10^{11}\end{array}$ & - & - & $\begin{array}{c}1.09- \\
5.4 \times 10^{2}\end{array}$ & $\begin{array}{c}1-5 \times \\
10^{10}\end{array}$ & $\begin{array}{l}<1.8 \mathrm{x} \\
10^{4}\end{array}$ & $<1.92 \times 10^{13}$ & - & - \\
\hline
\end{tabular}




\section{Continued}

\begin{tabular}{|c|c|c|c|c|c|c|c|c|c|c|}
\hline \multicolumn{11}{|l|}{$\begin{array}{l}\text { Heat } 50 \% \text { of } \\
\text { metabolism }\end{array}$} \\
\hline$(* * \mathrm{~kg})$ & (600) & $2.77 \times$ & (500) & $1.04 \times$ & (100) & $4.9 \times$ & (50) & $3.31 \times$ & (2) & $4.29 \times$ \\
\hline W/day & 205.6 & $10^{11}$ & 179 & $10^{10}$ & 53.2 & $10^{10}$ & 31.4 & $10^{10}$ & 2.9 & $10^{10}$ \\
\hline W/year & $7.5 \times 10^{4}$ & $\begin{array}{l}1.01 \times \\
10^{14}\end{array}$ & $\begin{array}{c}6.53 \times \\
10^{4}\end{array}$ & $3.79 \times 10^{12}$ & $\begin{array}{c}1.94 \times \\
10^{4}\end{array}$ & $\begin{array}{c}1.78 \times \\
10^{13}\end{array}$ & $\begin{array}{c}1.14 \times \\
10^{4}\end{array}$ & $1.2 \times 10^{13}$ & $\begin{array}{c}1.05 \times \\
10^{3}\end{array}$ & $1.56 \times 10^{13}$ \\
\hline *calf W/day & 44.58 & $\begin{array}{c}6.02 \times \\
10^{10}\end{array}$ & - & - & - & - & - & - & - & - \\
\hline *calf W/year & $\begin{array}{c}1.62 \times \\
10^{4}\end{array}$ & $\begin{array}{l}2.18 \times \\
10^{13}\end{array}$ & - & - & - & - & - & - & - & - \\
\hline $\begin{array}{c}\text { Water } \\
\text { evaporation }\end{array}$ & & & & & & & & & & \\
\hline $\begin{array}{l}\mathrm{g} / 100 \mathrm{~kg} \\
\text { animal/hourly }\end{array}$ & \multicolumn{10}{|c|}{240} \\
\hline $\mathrm{g} / \mathrm{m}^{2} /$ hourly & $10-200$ & - & a.n. & - & a.n & - & a.n. & - & a.n & - \\
\hline $\begin{array}{l}\text { perspiration } \\
\text { l/hour }\end{array}$ & a.n & - & some litres & - & a.n & - & a.n & - & a.n & - \\
\hline \multicolumn{11}{|l|}{ Urine } \\
\hline 1/day & $10-15$ & $\begin{array}{c}1.35 \times \\
10^{9}- \\
2.02 \times \\
10^{10}\end{array}$ & $4-5$ & $\begin{array}{c}2.3-2.91 \times \\
10^{8}\end{array}$ & $2.5-4.5$ & $\begin{array}{c}2.3- \\
4.1 \times \\
10^{9}\end{array}$ & $0.6-1.0$ & $\begin{array}{c}6.3 \times 10^{8}- \\
1.05 \times \\
10^{9}\end{array}$ & a.n. & a.n. \\
\hline 1/year & $\begin{array}{c}3.6-5.4 \\
\times \\
10^{3}\end{array}$ & $\begin{array}{c}4.92 \times \\
10^{11} \\
-7.37 \times \\
10^{12}\end{array}$ & $\begin{array}{c}1.46-1.82 \times \\
10^{3}\end{array}$ & $\begin{array}{c}8.39 \times 10^{10} \\
-1.06 \times \\
10^{11}\end{array}$ & $\begin{array}{c}9.1 \times 10^{2}- \\
1.6 \times \\
10^{3}\end{array}$ & $\begin{array}{c}8.39 \times \\
10^{11}- \\
1.49 \times \\
10^{12}\end{array}$ & $\begin{array}{l}219- \\
365\end{array}$ & $\begin{array}{c}2.29- \\
3.83 \times \\
10^{11}\end{array}$ & a.n. & a.n. \\
\hline \multicolumn{11}{|l|}{ Faeces } \\
\hline kg/day & $10-30$ & $\begin{array}{c}1.35- \\
4.05 \times \\
10^{10}\end{array}$ & $15-23$ & $\begin{array}{c}8.73 \times \\
10^{8}- \\
1.33 \times \\
10^{9}\end{array}$ & $0.5-3$ & $\begin{array}{c}4.61 \times \\
10^{8}- \\
2.76 \times \\
10^{9}\end{array}$ & $1-3$ & $\begin{array}{c}1.05- \\
3.16 \times \\
10^{9}\end{array}$ & $\begin{array}{l}0.1- \\
0.15\end{array}$ & $\begin{array}{c}1.48- \\
2.22 \times \\
10^{9}\end{array}$ \\
\hline kg/year & $\begin{array}{c}3.65 \times \\
10^{3}- \\
1.09 \times \\
10^{4}\end{array}$ & $\begin{array}{c}4.92 \times \\
10^{12}- \\
1.47 \times \\
10^{13}\end{array}$ & $\begin{array}{c}5.47- \\
8.39 \times \\
10^{3}\end{array}$ & $\begin{array}{c}3.18- \\
4.85 \times \\
10^{11}\end{array}$ & $\begin{array}{l}182- \\
1095\end{array}$ & $\begin{array}{c}1.68 \times \\
10^{11}- \\
10^{12}\end{array}$ & $\begin{array}{l}365- \\
1095\end{array}$ & $\begin{array}{c}3.83 \times \\
10^{11}- \\
1.15 \times \\
10^{12}\end{array}$ & $\begin{array}{l}36.5- \\
54.75\end{array}$ & $\begin{array}{c}5.4-8.1 \times \\
10^{11}\end{array}$ \\
\hline $\begin{array}{c}\text { Water content } \\
\text { in } \%\end{array}$ & $80-85$ & - & $70-80$ & - & $55-75$ & - & $55-75$ & - & a.n. & a.n. \\
\hline
\end{tabular}

Manure

$\mathrm{kg} / \mathrm{animal} /$ day

Depending on the species of animals and the mode of breeding

Sewage

\begin{tabular}{|c|c|c|c|c|c|c|c|c|c|c|}
\hline 1/day & $30 * * *$ & $\begin{array}{c}4.05 \times \\
10^{10}\end{array}$ & $30 * * *$ & $\begin{array}{c}1.74 \times \\
10^{9}\end{array}$ & a.n. & a.n. & a.n. & a.n. & a.n. & a.n. \\
\hline 1/year & $\begin{array}{c}1.09 \times \\
10^{4}\end{array}$ & $\begin{array}{c}1.47 \times \\
10^{13}\end{array}$ & $1.09 \times 10^{4}$ & $\begin{array}{c}6.37 \times \\
10^{11}\end{array}$ & a.n. & a.n. & a.n. & a.n. & a.n. & a.n. \\
\hline
\end{tabular}

Abbreviations: $*$ experimental datum of one calf of $75 \mathrm{~kg} ;(* *)=$ body mass; $* * *=30$ l-s in each animal species $/ 500 \mathrm{~kg} /$ day; a.n. = datum is unknown; - = no datum.

animals as well as the plants living in the Biosphere.

\section{Importance of Fire}

Originally the heat load of the Earth has come from the Sun. (Here we do not deal with the own heat of the Earth.) Before the biological life the sun-shine had a direct physical effect on the surface of the Globe. After the appearance of the life it has been effective in two ways: directly and through the metabolism of living organisms. This situation has been changed after the appearance of the first human being who discovered the significance of fire and later the man kind have started to require other type of energies than heat. First people started to use/ liberate organically bounded heat of the Sun with burning of flammable materials. Initially, the major sources of 
that heat were trees and woody plants as well as other flammable organic materials e.g. dung. Although coal, mineral oil and various flammable gases were known already in antiquity these raw materials were not used extensively for a long time. The situation became more complicated after the discovery of natural energies (water, wind, and so on) and when it was observed that heat is produced during the composting process.

In England coal was regularly mined as early as the 1500s. However, the intensity of exploitation has started to increase significantly only after the discovery of the steam engine in 1778 and the beginning of the extensive use of that type of machines. Photosynthesis was first described in 1779. The first steam engine and the first steam ship were launched in the first decade of the 1800s. The production of electricity became possible with the discovery of inductance. Exploitation of mineral oil started to increase from 1860. Hydroelectric stations have been used to produce electricity since 1866. The Otto-engine which is the predecessor of the present internal combustion engines was invented in 1876 and since that point of time not only improvement of that type of engines but also various means of transportation have started to develop endlessly with all the unpleasant consequences of these processes. The use of natural gas has started to increase since the 1880s and it became extensive all over the world in the $20^{\text {th }}$ century only. The first thermal power station producing electricity was built by Edison, moreover the first windmill generating the same energy was also constructed at around the same time in North America. However, the production of that type of energy only became general in the second half of the last century following the oil crisis and the necessary technological developments.

Since the discovery of photocell solar energy has not only been harnessed by simple absorption or with a more effective way using mirrors and lenses, but in a photo-electric way, as well. It was also discovered that with the help of the metabolic activity of micro-organisms flammable materials e.g. methane or bio-alcohols or other substances can be obtained. On the basis of this knowledge production of energetic raw materials started. It was discovered in 1942 that heat energy can be generated by nuclear reactions and since 1954 this process has been used in atomic power stations as a method to obtain energy. Lately, novel sources of energy have been introduced such as bio-diesel of plant origin prepared from rapeseed, $\mathrm{H}_{2}$ obtainable from water and burning of various waste materials produced by man kind including plastics. Moreover, experiments are strongly forced to get the possibility of the use of nuclear fusion.

\section{Environmental Effects of Products of Combustion and That of the Metabolism of Living Organisms}

It is evident that when any organic material is burnt/oxidized heat and various products of combustion are produced depending on the constitution and amount of the material burnt as well as on the form of burning. These products of combustion have burden the natural composition of the environment. In the metabolic processes of living organisms while chemical energy of single compounds is utilized heat and other metabolic products are also formed and excreted according to the general laws of the physical, chemical and biological processes. Only a few of these combustion and metabolic products are listed here: $\mathrm{CO}_{2}, \mathrm{CO}, \mathrm{H}_{2} \mathrm{O}$, nitrogen oxides, sulphur oxides, methane and other compounds. (It is also worth mentioning that there are large $\mathrm{CO}_{2}$ and methane fields under the surface of the Globe.) The quantity of all of these substances over a limit may be dangerous/toxic to the natural environment and some of them have glass-house effect, too. (At present we have some options to eliminate surplus $\mathrm{CO}_{2}$. In case of physical burning one possibility is to collect the smoke and press it into suitable spaces of the Earth such as into abandoned oil wells. The other one is to convert $\mathrm{CO}_{2}$ into stable chemical compounds, e.g. calcium carbonate and store it in that form. A further method is to use it up from the atmosphere by photosynthesis and the products after harvest are closed into the depth of the Globe.)

In case of physical burning one part of the energy released which is not used for work burdens the environment. In case of living organisms one part of the chemical energy which is liberated during metabolic processes of warm-blooded/homoiothermic animals (birds and mammals) is used for self-sustenance as well as work and the rest leaves the organism and gets into the environment as heat. (Plants, microorganisms and cold-blooded/ poikilothermic animals also produce metabolic products- $\mathrm{O}_{2}, \mathrm{CO}_{2}$, water and so on-during their life.)

Warm-blooded animals adapting to the changing external temperature keep their normal body temperature by altering the intensity of their metabolism and by expelling water and/or heat in the form of expiration, evaporation, perspiration, radiation, flow and conduction. $2.51 \mathrm{~kJ}$ energy is needed to evaporate $1 \mathrm{~g}$ of water. An animal weighing $100 \mathrm{~kg}$ needs to evaporate $240 \mathrm{~g}$ of water per hour to maintain its heat balance. This is equivalent to $167 \mathrm{~W}$ or $603 \mathrm{~kJ}$. Based on the measured data it is assumed that approx. half of the chemical energy produced in 
the body of an animal is emitted as heat into the environment. At present it is not known how much heat is liberated during metabolism in the human body and how much of it gets into the environment. Considering the $50 \%$ heat loss in case of animals we estimate this value to be $25 \%$ but acknowledge that this value is only an assumption. Incidentally, humans defend themselves from heat loss through radiation, flow and conduction with the use of clothes, buildings and artificial heating systems.

\section{Possibilities to Obtain Energy}

Man kind may get energy in the following ways:

- By direct or indirect collection of solar energy.

- From geothermal energy pumped from the earth or collected from geysers.

- Utilizing biomasses, that is renewable resources.

- With burning of non-renewable fossil fuels such as coals, mineral oils and natural gases. These were formed through the transformation of fossilized organisms that lived millions of years ago.

- Either by direct use of water and wind energy or in the form of electricity produced with their help.

- Utilizing heat obtained from atomic reactions.

- Burning waste materials or using methane obtained from deposited waste.

- Using $\mathrm{H}_{2}$ obtained from water.

It is well-known that the amount of heat energy obtainable from an inflammable substance is determined by its calorific value but in practice this potency can only partially be realized depending on the efficiency of the releasing process. There is no energy which can totally be converted by burning to heat in the practice as products of combustion are also formed and the heat produced cannot be fully utilized. In the next chapter we discuss the problems connected with the different energies which can be captured, mined, released and utilized by man kind.

\section{1. "Constant" Energies}

At present there are two "constant" sources of energy in the Biosphere. One of them is obviously the Sun. Its energy can be used in direct and indirect forms. The other one is the still existing geothermal energy of our Globe.

As for solar energy it was mentioned above that its amount is supposed to be nearly constant over the years: c. $510,100,000 \times 365 \times 24 \times 3600 \times 1,000,000 \mathrm{~kJ} / \mathrm{m}^{2}$. However, this calculation raises problems in connection with the interpretation of the solar constant. It is well-known that the amount of solar energy that can be measured at one point/area of the Earth's surface in a given unit of time is influenced by at least five factors. These are: the fact that the Globe is spherical and it turns, its axis of rotation is not vertical, it revolves around the Sun on an elliptical orbit and that the composition of the atmosphere above the area is variable. In consequence of these factors the amount of energy arriving at a given point/area of the surface shows a regular (at least daily) fluctuation. The amount of energy changes between 0 at night and the maximum value at noon. Therefore, not the same amount of energy reaches different points of the Earth's surface every day at the same point of time, even if the actual condition of the atmosphere above the receiving point is disregarded. We are not able to give an exact answer to this problem. The question can be raised whether it is known how much energy reaches the Earth in a given unit of time. The next question is how the actual heat capacity of a given "receiving area" can influence the absorption, reflection, physical storage, radiation and utilization by photosynthesis of the same amount of solar energy.

Solar energy can be "trapped artificially" and utilized through its direct heating effect or in photo-electric way. At present both methods are employed on the Globe and in space as well. We do not have any knowledge about the total amount of solar energy utilized in these ways.

The other option is the natural utilization of solar energy. On this way photosynthetic organisms bind—or "are made to bind"- - solar energy and later these organisms or their products, that is the biomasses (renewable energy sources or sources of bioenergy) are utilized by humans in the form of food or fodder by keeping farm animals, burning of plants either in a natural or in a transformed form, for example as bio-substances.

As the growth period of trees may be several decades or sometimes even some hundreds years, forests can be considered as transitional forms between renewable and non-renewable sources of energy. The amount of solar energy bound yearly by all kinds of the photosynthetic organisms is unknown. These organisms can utilize $\mathrm{CO}_{2}$ 
and produce $\mathrm{O}_{2}$ or they should consume $\mathrm{O}_{2}$ depending on the light conditions.

\subsection{Renewable Sources of Energy}

\subsubsection{Plant/Tree-Based Energy}

Regarding forests sporadic data are available even from antiquity. Deforestation also started in the ancient times and its detrimental effect soon became obvious. The total size of forests was estimated to be 5.5 billion hectares in 1882. Then this area represented $36.9 \%$ of the continents. By 1960, this ratio fell to $29 \%$ and in 2005 it was only 4.0 billion hectares which is only $26.8 \%$. At present the dimension of forested areas is decreasing by 13 million hectares yearly which is equivalent to a loss of $0.3 \%$ annually. The total decrease is very remarkable. If 5.5 billion hectares are considered to be $100 \%$ then by 2015 29.63\% of this highly important regulatory system was lost. This loss may be responsible for a certain part of the recent climatic changes as substitution of the great rain forests with artificial establishments or agricultural use cannot restore the original conditions because the heat capacity, $\mathrm{O}_{2}$ production, $\mathrm{CO}_{2}$ binding ability, role in the water cycle or the ecological function of the new constructions are different from those of the original ones. It was not expected that the rate of decrease of forested areas has not slowed down during the last 133 years even in the past decade the estimated loss of $0.3 \%$ annually appears to be somewhat more than the annual average of the previous 123 years, which was only 12.19 million hectares per year.

Dőry István wrote to us in his letter that one hectare of forest in the temperate zone produces c. $104 \mathrm{~kg}$ of wood and its energy yield is approximately $10 \mathrm{MJ} / \mathrm{m}^{2} /$ year. His opinion is that in Hungary the ratio between the volume in $\mathrm{m}^{3}$ and raw weight in tonnes of trees is 8 to 5 , that is, 0.62 . However, a year later this ratio is only 0.5 due to drying. The calorific value of raw wood is around $6.8 \mathrm{MJ} / \mathrm{kg}$ depending on its species. The value may increase to $14.4-15.8 \mathrm{MJ} / \mathrm{kg}$ when the water content of the wood decreased. According to some Finnish data 700 $\mathrm{kg} / \mathrm{m}^{3}$ raw tree is equivalent to $350 \mathrm{~kg}$ dry wood and contains $175 \mathrm{~kg}$ carbon from which $642 \mathrm{~kg} / 324.2 \mathrm{~m}^{3} \mathrm{CO}_{2}$ is released into the air during burning. $60 \%$ of the trees cut down are burned in the form of lumber. As for the energetic role of wood exact quantitative data are unknown. According to some estimates, only a few per cent of the total energy requirement of the Earth is provided by burning wood, during which process products of combustion-e.g. $\mathrm{CO}_{2}$, wood ash-are also formed.

Energy from woody plants other than trees should also be mentioned. The calorific value of these biomasses is similar to that of trees or even slightly higher (around $16 \mathrm{MJ} / \mathrm{kg}$ ) because their water content is lower. It is an advantage of these plants that they can be regrown each year. Their products of combustion are similar to those of trees. Nonetheless, due to their short-around one year long-biocycle they play an even smaller role than trees in the elimination of $\mathrm{CO}_{2}$, as the $\mathrm{CO}_{2}$ they bind is released in the same year. Their energetic significance is unknown due to the lack of exact data.

Flammable biogas can be obtained from certain biomasses, as a result of microbial activity in anaerobic conditions at temperatures of $30^{\circ} \mathrm{C}-55^{\circ} \mathrm{C}$ depending on the method used. Biogas is a mixture of mainly methane (50\% - 70\%) and $\mathrm{CO}_{2}$. Methane has a high calorific value at $32.7 \mathrm{MJ} / \mathrm{m}^{3}$. Burning $1 \mathrm{~m}^{3}$ of methane yields $1 \mathrm{~m}^{3}$ of $\mathrm{CO}_{2}$ depending on the temperature. Data on the total amount and energetic significance of biogas produced artificially by man kind and emitted into the atmosphere are not known. Similarly the amount of methane which originates from mines is also unknown.

Biomasses with high sugar content can be used to produce alcohol through the necessary microbiological processes. Bio-alcohol obtained this way is used in several countries as a petrol substitute. The calorific values of different types of alcohol range between 19.9 and $26.8 \mathrm{MJ} / \mathrm{kg}$. When they are burned $\mathrm{CO}_{2}$ is also released. Their real significance cannot be determined because of the lack of quantitative data.

Plant products with high lipid content (and also used cooking oil, animal fats and lipid wastes) can be converted into bio-diesel. The calorific value of this material is $37 \mathrm{MJ} / \mathrm{kg}$. It can be used as a substitute for diesel oil refined from mineral oil, but it has an unpleasant smell. With its use $\mathrm{CO}_{2}$ is released into the air. The total amount and energetic significance of bio-diesel produced are unknown.

Composting should also be mentioned at this point, which has two basic forms: the classic and the so called fast method. The essence of composting is that organic substances are degraded and converted by microorganisms in aerobic conditions. Composting is an exothermic process during which temperatures may reach $50^{\circ} \mathrm{C}$ $70^{\circ} \mathrm{C}$. We have no information on how this heat is utilized. During composting $\mathrm{CO}_{2}$ is formed and the end products can be used in agriculture as organic fertilizers. It is uncertain how much organic material is composted and how much heat and $\mathrm{CO}_{2}$ are released. 


\subsubsection{Geothermal Energy}

This type of energy can be harnessed by taking out the still existing heat content of the Earth in the form of hot water or steam as well as by utilizing the heat energy of geysers. These energies are primarily used for heating buildings, glass-houses and so on, but they are not available everywhere due to differences of the geothermic gradient and the fact that geysers are not found in every place. The total quantity of that type of energy is not known. For us it is also unknown how much of its own heat is radiated by the total Globe-continents and waters-during one year.

\section{3. Natural Sources of Energy}

These sources of energy "last forever", at least in theory, but actually the capacity of each type of energy source is influenced by a number of factors, even in the same place — such as seasons, weather conditions and so on-, not to mention the fact that they only occur naturally in certain geographical regions. It must be added, though, that the conditions of employing hydropower can also be created artificially in some suitable areas.

\subsubsection{Hydropower}

This type of energy was already known in the ancient times (e.g. in the form of mills, water lifting installations, systems of drinking water, canals). Moreover, some Greek philosophers even described the process of the "water cycle", too. Currently several types of hydropower plants are constructed. In one of the main types the turbines are moved by the potential energy of the dammed-up river water. In the other one, the rotation is caused by the tidal waves of the sea, elicited by the Moon. At present hydropower is used to produce electricity in over 160 countries of the world. Electricity production in hydropower plants started in 1866. By 1973 the output of these power plants reached 1296 TWh, it was 3000 TWh by 2005-06 and 3756 TWh in 2012. According to other data, in 2010 the total capacity of the 11000 hydropower plants all over the world was 874 GW altogether, which gave $16 \%$ of the total electricity production. Hydropower can be considered to be a "clean" type of energy.

Here, it is necessary to mention that water can also be used as a raw material for the production of $\mathrm{H}_{2}$.

\subsubsection{Wind Energy}

This type of energy was also used as early as in antiquity (e.g. as sailing boats, mills, water lifting installations). Beside the mechanical work of wind technical development and the arising need of energy forced the spread of modern wind power stations producing electricity. Their widespread application is hindered by the lack of permanent and strong enough wind in many areas. The first wind power station with an output of 0.3 MW was constructed by Russian engineers in 1931. According to some statistics, wind power stations provided 59,091 MW of electricity in 2005, while by 2013 this value increased to 318,105 MW. Other statistics show that $74.2 \mathrm{GW}$ of energy was obtained from wind power in 2006. Still other data show that 47.2 TWh electricity was produced in 2013 using wind power stations. Wind power can be regarded as a "clean" type of energy as well.

\subsection{Non-Renewable Sources of Energy}

These include mineral oils, coals (black coal, brown coal, lignite, peat) and natural gases, as well as products manufactured from these such as kerosene, petrol, petroleum, diesel oil, fuel oil, oil gas, coke and so on). The term "non-renewable" is only valid compared to the human lifespan, as the three raw materials listed above may at present also be formed slowly anywhere where adequate conditions are present. The calorific values of these raw materials differ depending on their quality. The calorific value of oils is around $33-48 \mathrm{MJ} / \mathrm{kg}$, of natural gases, $32-42 \mathrm{MJ} / \mathrm{m}^{3}$ and of coal types $8-32 \mathrm{MJ} / \mathrm{kg}$. By burning the materials listed different types of work may be done. The heat energy released may be employed directly (e.g. moving vehicles) or in a converted form as electricity. According to the data of the International Energy Agency in 2010 the energy produced on the Earth had the following origins (in order of importance): mineral oils $33 \%$, coals $27 \%$, natural gases $21 \%$, hydro energy $10 \%$, nuclear energy $6 \%$, wood $2 \%$ and other sources $1 \%$.

We saw another data which appeared in 2014 that in 1973 the sources of energy used up all over the world were: mineral oils $46.1 \%$, coals $24.6 \%$, natural gases $16.0 \%$, biomasses and wastes $10.5 \%$, hydro energy $1.8 \%$, nuclear energy $0.9 \%$ and other sources-geothermal, solar, wind energy and so on- $0.1 \%$. In the same book it can be read that by 2013 the ratio of energy sources had undergone changes: mineral oils $31.4 \%$, coals $29.0 \%$, 
natural gases $21 \%$, biomasses and wastes $10 \%$, nuclear energy $4.8 \%$, hydro energy $2.4 \%$, and other sources $1.1 \%$. According to yet another source, man kind covered their energy needs from the following sources: mineral oils $34 \%$, coals $24 \%$, natural gases $20 \%$, hydro energy, wind and solar energy $10 \%$, both nuclear energy and biomasses also $6 \%$ each, that means, only $12 \%$ of all came from renewable sources.

It is important to point out that with the production of 1 MWh energy from coal $755 \mathrm{~kg} \mathrm{CO}_{2}$ is released into the atmosphere, while using mineral oil this value is only $580 \mathrm{~kg}$ and with natural gas it is an even lower value of $385 \mathrm{~kg}$. It is also worth noting that $\mathrm{CO}_{2}$ is formed even during the production of "clean" types of energy. e.g. during the production of $1 \mathrm{MWh}$ nuclear energy $11-22 \mathrm{~kg} \mathrm{CO}_{2}$ goes into the air. When wind power is used this value is $11-37 \mathrm{~kg}$ and in case of biomasses it is $29-32 \mathrm{~kg}$. While burning kerosene only heat, $\mathrm{CO}_{2}$ and water are produced using all the other mineral oil derivatives different other products of combustion go into the air e.g. nitrogen oxides - changing its composition and glass-house effect. During burning $100 \%$ pure natural gas, that is, methane, only heat, $\mathrm{CO}_{2}$ and water get into the atmosphere. However, when coal is burned, apart from heat, $\mathrm{CO}_{2}$ and water, various other polluting materials-e.g. sulphur oxides-may be found in its smoke, increasing the danger of acid rains. While burning $1 \mathrm{~kg}$ of coal (anthracite) produces $2.3 \mathrm{~kg} / 1.16 \mathrm{~m}^{3} \mathrm{CO}_{2}, 1 \mathrm{~kg}$ of mineral oil gives off $3.17 \mathrm{~kg} / 1.6 \mathrm{~m}^{3} \mathrm{CO}_{2}$ and for natural gases, the equivalent values are $2.8 \mathrm{~kg} / 1.4 \mathrm{~m}^{3}$.

It is difficult to evaluate the problems connected with these energy sources as the exact amounts of mineral oils, coals and natural gases of different calorific values are not available, therefore, it is unknown exactly how much heat can be obtained from them, or how much $\mathrm{CO}_{2}$ and other polluting materials are released. We show an example in Table 5. You can see that burning the same quantity of gases with differing calorific values different amounts of heat were obtained. Using the average of the two calorific values we get a third number. As the amounts of gases with differing calorific values are not known separately it is certain that the calculations are only approximate.

\subsection{Other Sources of Energy}

\subsubsection{Nuclear Energy}

At present, over $6 \%$ of the total energy need by man kind is ensured by nuclear power stations. This type of energy is independent from solar radiation. According to a datum in 2007 there were 439 nuclear power stations in 31 countries of the Globe. 15 out of the 27 member states of the European Union have one or more nuclear power stations including Hungary, too. The first such station in the World started to produce electricity in 1954 with an output of 5 MW. The total output of nuclear power stations was 203 TWh in 1973. According to the Key World Energy Statistics this value increased to 2697 TWh by 2009. A special form is to use nuclear energy to power aircraft carriers and icebreaker ships. In each nuclear power station during nuclear reaction a large amount of heat is produced together with the so called "products of combustion", that is radioactive wastes and cooling water. Only about one third of the heat energy released can be utilized in the form of electrical energy the rest is loss. (It should be mentioned that a huge amount of heat and radioactive materials have been released into the environment during nuclear experiments and military explosions. Earlier these events happened in the air and on the surface of the Earth recently only under ground. Each explosion has short term as well as longterm effects similarly to an accident of a nuclear power station.

\subsubsection{Hydrogen Energy}

Because of military and space exploratory reasons no exact data are known about the quantity of $\mathrm{H}_{2}, \mathrm{O}_{2}$ and other types of fuels used by rockets. It is also uncertain how many rockets leave the Earth annually and what type

Table 5. Calorific value of natural gases depending on their quality.

\begin{tabular}{ccccc}
\hline Subject & $\begin{array}{c}\text { Natural gas used } \\
\left(\text { billion } \mathrm{m}^{3}\right)\end{array}$ & \multicolumn{1}{c}{ Calorific value (billion MJ) } & Average \\
\hline Year & & $\min .32 \mathrm{MJ} / \mathrm{m}^{3}$ & $\operatorname{max.} 42 \mathrm{MJ} / \mathrm{m}^{3}$ & $37 \mathrm{MJ} / \mathrm{m}^{3}$ \\
\hline 1935 & 0.071 & 2272 & 2982 & 2627 \\
1958 & 0.400 & 12,800 & 16,800 & 14,800 \\
1980 & 1.531 & 48,992 & 64,302 & 56,647 \\
2013 & 3479 & 111,328 & 146,118 & 128,723 \\
\hline
\end{tabular}


of fuel they use. Only a few data are presented on rocket engines run by the mixture of liquid hydrogen and oxygen. These engines typically burn $700-2000$ metric tons of a $\mathrm{H}_{2}$ and $\mathrm{O}_{2}$ mixture during $120-180 \mathrm{~s}$. The calorific value of $\mathrm{H}_{2}$ is $9.9 \mathrm{MJ} / \mathrm{m}^{3}$. When $1 \mathrm{~kg}$ liquid hydrogen is burnt $141.97 \mathrm{MJ}$ of heat is released, but burning the same amount of gaseous $\mathrm{H}_{2}$ "only" $119.6 \mathrm{MJ}$ of heat is produced. In accordance with these values burning the $700-2000$ metric tons of $\mathrm{H}_{2}$ under a few minutes depending on whether it is a liquid or a gas $\mathbf{9 . 9 3 7 9} \times$ $10^{7}-2.8394 \times 10^{8}$ or $8.372 \times 10^{7}-2.392 \times 10^{8}$ MJ of heat burdens the environment! Fortunately the product of combustion is only water. The environmental effect of rockets with other types of engines is a different and more complex problem as when these work not only heat but other harmful products of combustion are also formed. Because of these the overall role rockets play in the heat load and the contamination of the environment is unknown. Similarly, there is no information available on the total amount of $\mathrm{H}_{2}$ produced and used for other purposes, either.

\subsubsection{Energy from Wastes}

Waste is a collective term, including biomasses as well as communal, agricultural, industrial, transport and other waste materials. We do not deal with the special problems of hazardous wastes. Waste can be controlled by selection and recycling, biological methods, combustion as well as deposition. Selection and recycling are not detailed here. Biological methods have already been described in relation to biomasses. Besides the above mentioned methods a further option is heat treatment to utilize the bound energy and/or eliminate wastes. Two types of heat treatment are known: one is combustion or the oxidative method the other is pyrolysis performed in reductive circumstances.

Combustion is an exothermic, self-sustaining process which generally has to be done at temperatures of $600^{\circ} \mathrm{C}-900^{\circ} \mathrm{C}$ and after that process the gases have to be burnt at $1000^{\circ} \mathrm{C}-1200^{\circ} \mathrm{C}$ (so called the post-combustion) in order to avoid the emission of toxic materials. Besides gases solid products of combustion are also formed. $60 \%$ - $80 \%$ of the heat liberated during burning can be used to produce steam the rest loads the environment. The number and capacity of waste incinerators and the quantity of heat and electricity produced by them are unknown.

Pyrolysis is a process which goes on in reductive conditions by applying heat.

From deposited wastes during their decomposition methane may be formed which can be utilized in the recent technological circumstances.

It should be noted that certain gases and heat are also emitted during the operation of sewage treatment plants. Sewage sludge can be regarded as biomass and in modern applications it is treated as such. The number of plants and their capacity as well as the total amount of sewage water treated, sludge formed and emissions are unknown. Here we do not deal with the qualitative and quantitative problems of animal husbandry as we have not data.

\subsubsection{Electricity}

In the following we deal with the problems of electricity, that is, the amount of electrical energy produced and used by man kind and some related issues. Electrical energy may be obtained with the help of a dynamo/generator or with the use of a photoelectric cell. To get electricity it is necessary to turn the rotors by any kind of power which can be produced by combustion, by an atomic physical process or using the energy of water or wind. According to the Key World Energy Statistics in 19736115 TWh electricity was produced, while in 2009 this value was 20055 TWh.

It could be read in another paper that out of the total quantity of electricity $30.2 \%$ was produced burning brown coal, $23.0 \%$ by black coal, $18.8 \%$ using uranium, $9.8 \%$ with wind energy, $8.2 \%$ burning gas, $6.1 \%$ by solar energy and 3.2\% with water energy. (Surprisingly mineral oil, wood and other flammable materials— such as wastes or biomasses-were not mentioned in this study. It is also unclear whether the expression "running water" includes tidal power stations, too or not. Also what does the word "gas" exactly mean-natural gas, biogas and "town gas" together or only one or two out of the three?) The environmental contamination effect of electricity depends on either how much of it is converted to work and lighting because the rest is lost as heat or what kind of methods is used to produce it because the burdening effect of the methods used is quite different.

\section{Discussion}

The data of Figure 1 and Table 6 show the number of man kind, the quantity of raw materials mined and the 


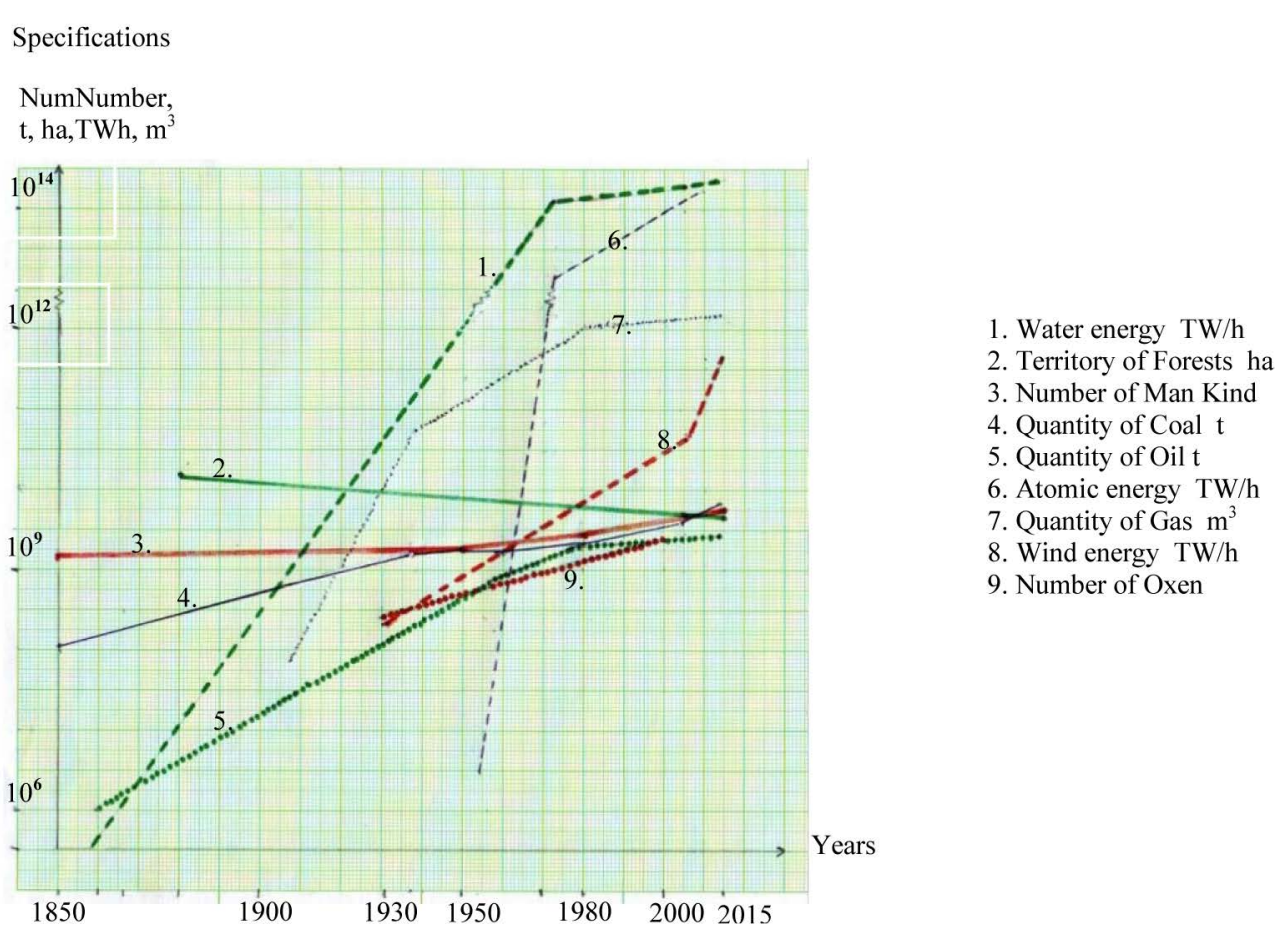

Figure 1. Numbers of man kind and oxen; quantities of raw materials and energies; dimension of territory of forests between $1850-2015$.

energies produced, as well as the area of forests, the number of oxen and the results of our calculations on the circulation of energy and substance in a combined form. It must be emphasized that the data presented represent the quantities of each subjects of a given year only! They show only tendencies. Summarized values for the total 165 years would obviously be higher than the ones presented. Also, it must be pointed out that events should be considered and evaluated as complex processes; otherwise inaccurate conclusions may be drawn.

As it was mentioned above our work was made difficult by the fact that single publications and statistics contain different data sometimes in distinct units and that the data of certain parameters were missing. In spite of this fact on the basis of the presented data we can evaluate the biological, thermal and chemical changes of the Biosphere that happened during the last more than 150 years. It can be concluded that while during that years the number of humans (see Figure 1) as well as farm animals (you can see them in Table 1) has increased continuously, the area of forests has decreased permanently. It is also a fact that the production of life needs (by mining, manufacturing, cultivating, breeding and so on) for humans and animals is an increasing problem and that during these efforts the degree of environmental contamination has also become more serious. For example the quantity of $\mathrm{CO}_{2}$, methane, water vapour, heat and other polluting materials as well as the degradation in the quality of soils and waters have increased. Due to the loss of forested areas the general multifunctional positive effect of forests has been weakening. The heat capacity and ecological function of the reused areas are quite different from the original natural ones. Also, it cannot be denied that a strong process of urbanization is going on at the same time, with all its unfavourable consequences. Not only the amount and consumption of energy produced, released and captured by humans increased, but also the quantity of burdening heat as well as energetic and industrial raw materials used is permanently increasing and the ecological load is augmenting, too. Thus, the amount of $\mathrm{CO}_{2}$, nitrogen and sulphur oxides, methane, different type of metals and so on is growing in the atmosphere. Perhaps the recent protective measures stopped or at least decreased the emission of CFC gases which deteriorate the ozone layer in the atmosphere or the increasing incidence of acid rains. There are no regular data available on the long term change of the water vapour content in the atmosphere. The changes in the original constitution of the atmosphere are undeniable. These changes surely influence the capacity of the atmosphere to reflect as well as absorb the Sun rays and retain the heat originated from the Sun, produced by man kind, emitted by living organisms and radiated by the Globe, but it is uncertain which of these and to what extent. The recent warming has started a vicious circle leading to a decrease in snow and ice fields and to a rise 
Table 6. Data on the circulation of energy and $\mathrm{CO}_{2}$ on the Earth.

\begin{tabular}{|c|c|c|c|c|c|c|}
\hline \multirow[t]{2}{*}{ Specifications } & \multicolumn{6}{|c|}{$\begin{array}{l}\text { Mass of fuels and their average thermal values. quantity of } \mathrm{CO}_{2} \text { liberated from fuels; other } \\
\text { energies; number and emissions of man kind and oxen at different points of time }\end{array}$} \\
\hline & 1860 & $1935+37$ & 1958 & 1980 & $2000+05$ & $2009+14$ \\
\hline Oil $\times 10^{6} \mathrm{t}$ & 1 & 279.5 & 809.8 & 3059 & 3590 & 4117 \\
\hline $40.5 \mathrm{MJ} / \mathrm{kg}$ & $4.05 \times 10^{10}$ & $1.13 \times 10^{13}$ & $3.27 \times 10^{13}$ & $1.23 \times 10^{14}$ & $1.45 \times 10^{14}$ & $1.66 \times 10^{14}$ \\
\hline $\mathrm{CO}_{2} \mathrm{~m}^{3}$ & $3.17 \times 10^{9}$ & $8.86 \times 10^{11}$ & $2.56 \times 10^{12}$ & $9.69 \times 10^{12}$ & $1.13 \times 10^{13}$ & $1.3 \times 10^{13}$ \\
\hline Coal $\times 10^{6} \mathrm{t}$ & 136 & 1280 & 1762 & 2805 & 5878 & 7823 \\
\hline $20.35 \mathrm{MJ} / \mathrm{kg}$ & $2.76 \times 10^{12}$ & $2.6 \times 10^{13}$ & $3.58 \times 10^{13}$ & $5.7 \times 10^{13}$ & $1.18 \times 10^{14}$ & $1.59 \times 10^{14}$ \\
\hline $\mathrm{CO}_{2} \mathrm{~m}^{3}$ & $3.12 \times 10^{11}$ & $2.92 \times 10^{12}$ & $4.05 \times 10^{12}$ & $6.45 \times 10^{12}$ & $1.37 \times 10^{13}$ & $1.72 \times 10^{13}$ \\
\hline Gas $\times 10^{9} \mathrm{~m}^{3}$ & a.n. & 71 & 400 & 1531 & 2778 & 3479 \\
\hline $37 \mathrm{MJ} / \mathrm{kg}$ & a.n. & $2.62 \times 10^{12}$ & $1.48 \times 10^{13}$ & $5.66 \times 10^{13}$ & $1.02 \times 10^{14}$ & $1.28 \times 10^{14}$ \\
\hline $\mathrm{CO}_{2} \mathrm{~m}^{3}$ & a.n. & $1.37 \times 10^{11}$ & $7.72 \times 10^{11}$ & $2.95 \times 10^{12}$ & $5.36 \times 10^{12}$ & $6.72 \times 10^{12}$ \\
\hline \multicolumn{7}{|l|}{ TOTAL } \\
\hline $\mathrm{MJ} / \mathrm{kg}$ & $2.8 \times 10^{12}$ & $3.99 \times 10^{13}$ & $8.33 \times 10^{13}$ & $1.8 \times 10^{14}$ & $3.66 \times 10^{14}$ & $4.53 \times 10^{14}$ \\
\hline $\mathrm{CO}_{2} \mathrm{~m}^{3}$ & $3.15 \times 10^{11}$ & $3.94 \times 10^{12}$ & $7.38 \times 10^{12}$ & $1.9 \times 10^{13}$ & $3.01 \times 10^{13}$ & $3.69 \times 10^{13}$ \\
\hline OTHER ENERGIES & 1866 & 1931 & 1954 & 1973 & $2005-2010$ & 2012-2014 \\
\hline Water TW/h & 0 & a.n. & a.n. & 1296 & 3000 & 3756 \\
\hline Wind GW & & $0.3 * * *$ & a.n. & a.n. & 59 & 318 \\
\hline Atomic TW/h & & & $5 * * *$ & 203 & 2461 & a.n. \\
\hline MAN KIND & 1850 & 1937 & 1950 & 1980 & a.n. & 2014 \\
\hline billion & 1.17 & 2.1 & 2.5 & 4.4 & a.n. & 7.5 \\
\hline $\mathrm{CO}_{2} \mathrm{~m}^{3} /$ year & $3.2 \times 10^{8}$ & $5.75 \times 10^{8}$ & $6.85 \times 10^{8}$ & $1.2 \times 10^{9}$ & a.n. & $2.05 \times 10^{9}$ \\
\hline $\begin{array}{l}\text { Heat } 25 \% \text { of } \\
\text { metabolism } \\
\text { W/year }\end{array}$ & $9.39 \times 10^{12}$ & $1.68 \times 10^{13}$ & $2.0 \times 10^{13}$ & $3.53 \times 10^{13}$ & a.n. & $6.02 \times 10^{13}$ \\
\hline OXEN & & 1930-ties & & & $1999-2000$ & \\
\hline million & & 438.9 & & & 1351.4 & \\
\hline $\mathrm{CO}_{2} \mathrm{~m}^{3} /$ year & & $4.98 \times 10^{10 *}$ & & & $1.53 \times 10^{11 *}$ & \\
\hline $\begin{array}{l}\text { Heat } 50 \% \text { of the metabolism } \\
\text { W/year }\end{array}$ & & $3.29 \times 10^{13}$ & & & $1.01 \times 10^{14}$ & \\
\hline Methane 1/year & & $\begin{array}{l}4.38 \times 10^{10}- \\
8.0 \times 10^{13 * *}\end{array}$ & & & $\begin{array}{l}4.93 \times 10^{11}- \\
2.46 \times 10^{14 * *}\end{array}$ & \\
\hline
\end{tabular}

Abbreviations: a.n. = datum is unknown; * = experimental datum of one calf of $75 \mathrm{~kg} ; * *=$ experimental datum of one cow of $600 \mathrm{~kg} ; * * *=\mathrm{MW}$.

in the temperature of surface waters. Incidentally, this may mean that the former heat buffering capacity of the Earth has decreased. The trophic states and ecological roles of waters are changing due to the increasing pollution and the rising temperature. As a consequence of human effects such as mining, industry, transport, large-scale fishing and agricultural production, the natural composition and activity of the plant and animal world, that is, the natural processes of the Biosphere are undergoing radical changes. Besides these, a forced increase of human demands is going on as well as the degree of indecency is also growing and these unfavourable changes further aggravate the situation.

After the formation of the Earth it has lived its own life through different periods of time which were already described in our earlier publications. Now only the names of these stages will be repeated. First, it is necessary to mention that the life of our Globe has two basically different parts. The first part is biologically lifeless and the second one is which started with the appearance of biological life. The first can be divided into the following periods: glowing star state; formation of the "recent" atmosphere, appearance of water as well as the start of the water cycle and finally formation of organic compounds in a sterile environment. That part of the Earth's life may be somewhat similar in case of each lifeless satellite which are similar to our Globe. At the end of this period life appeared and chemosynthesis started. From that point of time the life of the Earth is directed not only 
by the general physical laws of the lifeless Universe, but the special effects of biological life (from the first microbe till the present human society), too! The second part of the life of the Globe can be divided into the following stages: starting of the anaerobic chemosynthesis and later photosynthesis and finally the appearance of free $\mathrm{O}_{2}$; starting of "breathing"; development of multicellular plants and animals; advent of warm-blooded animals; appearance of the first human being and development of human society.

It is important to mention that the second part of the life of the Earth is determined by the effects of the biological factors, too, which are modified by the evolution, besides the lifeless universal effects. The biological effects of a given period have influenced on the balance of energy and substance flow of that period of time changing those and in consequence of this the formation of a new period starts. That type of events went on for example not only then when micro-organisms appeared (effects of their chemotrophic and later phototrophic metabolism - binding of $\mathrm{CO}_{2}$, starting of formation of organic soil, mud and the first ecosystem; appearance of free $\mathrm{O}_{2}$ and photosynthesis as well as breathing started) but during the past 165 years also (contamination of the Biosphere by human activities and farm animals). Therefore, it is reasonable to suppose that the causes of the perceptible increase in the average surface temperature of the Globe are the changes in the Biosphere that happened in consequence of the increasing number of man kind as well as farm animals and their effects, if it is indeed true that the arriving solar energy was more or less constant during that time. Therefore, if we summarise the quantity of heat emitted annually by humans and other heat-producing organisms since 1778 and also that of the heat released, produced and captured yearly by human beings together with the quantity of $\mathrm{CO}_{2}$, methane, nitrogen and sulphur oxides and so on emitted, we may get the annual values of those substances which could have played a role in the rise of the average surface temperature of the Earth, besides other factors not mentioned here. It is surely unimaginable that the changes mentioned before would have no effect on the condition of the total Biosphere. This is not made possible by the laws of nature! During the last 165 years, this continually increasing amount of energy used and liberated substances has a constant effect on the former natural energetic and substance condition as well as the total ecosystem of the Earth. The "extra heat and substances" which have artificially been formed since 1778 and are still forming, modify the original natural balance. This effect is further aggravated by the pollution of the Biosphere as a whole, the change of function in the original ecological system brought about by deforestation and other events, the possible modification of the water cycle and the change in the heat capacity of the Earth's surface.

Since its formation of our Globe has a given carbon content (this fact is not only true for $\mathrm{C}$ but also for all atoms, too), however, it is not known when it was formed and how large its quantity is. We have no data on whether any amount of $\mathrm{C}$ reaches the Earth from space and it is also unlikely that this atom is currently formed here. It is almost sure that the $\mathrm{C}$ atom or its compounds cannot leave the atmosphere toward the space in a natural way. Therefore, all changes related to $\mathrm{C}$ and its compounds have gone on in the original $\mathrm{C}$ depot of the Globe which is determined. Carbon may have appeared first in the form of methane and/or $\mathrm{CO}$ and/or $\mathrm{CO}_{2}$ but who knows in which form. By all means, the occurrence of $\mathrm{CO}$ and/or $\mathrm{CO}_{2}$ brought about significant effects on the Earth. $\mathrm{CO}$ and/or $\mathrm{CO}_{2}$ might have helped the formation of carbonates changing the $\mathrm{pH}$ of surface waters and gave the basis for the formation of simple organic compounds in sterile conditions, which process finally resulted in the formation of biological life.

When biological life (the first micro-organism) appeared and its (chemotrophic and later, phototrophic) anaerobic metabolism started, this process gave a definite direction to the $\mathrm{C}$ flow. During the original natural way $\mathrm{C}$ is bound by the organism for its life time and after its death this $\mathrm{C}$ is released during decomposition. This natural way later divided into two directions when one part of the organisms (unicellular plants, animals and other living organisms) sank from the surface of the Earth to its deeper region due to various geological processes and their substances containing $C$ remained in bound form. That means that one part of the $C$ together with its bounding energy left the "usual" cycle. These organisms have been transformed into oils, coals or methane and in consequence of this transformation not only their organic substances (that is C), but also the energies bound during their synthesis have remained stored. We little know about the biological cycle of these organisms therefore it is a secret how long they accumulated the energy of Sun during their life time and also how many organisms have been transformed into the energetic raw materials, therefore no information on how much energy and $\mathrm{C}$ were reserved and are currently stored yet. The mentioned event resulted in not only a removal of the $\mathrm{C}$ and energy from the natural energetic and substantial flow, but this process surely influenced the characteristic parameters of the Biosphere in that time, too.

More important utilization of coals, oils and natural gases started in 1778 or later and in consequence of that 
the energetic and substantial balance that had existed till that point of time started to change because of the liberation of the stored energy and C. If we would like to restore the original balance that had existed before 1778-which is impossible-the "surplus" $\mathrm{CO}_{2}$ and heat ought to be bound again. Otherwise, if $\mathrm{CO}_{2}$ remains in the atmosphere and the liberation of heat is continued they will induce a new equilibrium (to be precise, this process is already going on). Moreover, instead of the current trend of increasing energy production, all forms of heat release which are not absolutely necessary for maintaining biological life should be stopped in order to halt the process of warming. As $\mathrm{C}$ and its compounds cannot leave the Earth the surplus $\mathrm{CO}_{2}$ in the atmosphere could only be permanently reduced in the ways mentioned above: with binding $\mathrm{CO}_{2}$ by chemical methods and/or with cultivation of photosynthetic organisms which can use up $\mathrm{CO}_{2}$ and after the harvest their products ought to be closed deep down into the Earth. Burning is not a solution as it does not stop either the production of $\mathrm{CO}_{2}$ or the heat load of the Biosphere.

\section{Summary}

At present, in spite of the fact that we do not have all data connected with the processes going on in the Biosphere its condition can be evaluated. It can be diagnosed that the values of the measurable parameters-perhaps except one or two- - have changed/worsened although during the last decades many actions have been performed all over the World to stop or at least to reduce the unpleasant processes. This situation has existed in such a closed Biosphere in which the conditions of the persistence of biological life are determined and the sources are limited.

\section{References}

[1] Ralovich, B. (2011) Adatok a mikrobiológiával kapcsolatos ismeretek oktatás- és kutatástörténetéhez. I. kötet, Keszthely: TSR Kft.

[2] Ralovich, B. (2014) Adatok a mikrobiológiával kapcsolatos ismeretek oktatás- és kutatástörténetéhez. II. kötet, Keszthely: TSR Kft.

[3] Ralovich, B. (2014) Földünk helye a világmindenségben és fordulópontok az életében (Gondolatok a klímaváltozás kapcsán). Orvosi Hetilap, 155, 1367-1368.

[4] Ralovich, B. (2014) The Place of Our Earth in the Universe and Turning-Points in Its Life (Thoughts Induced by the Climate Change). AASCIT, 1, 116-119.

[5] Ralovich, B. (2015) Gondolatok és adatok a Földünk energetikai, kémiai es biológiai folyamataihoz. Orvosi Hetilap, 156. 749-751.

[6] Ralovich, B. (2015) Data to the Circulation of Energy and Substance on the Earth between 1850 and 2015. AASCIT, 2, 156-158.

[7] Simonyi, K. (1998) A fizika kultúrtörténete a kezdetektől 1990-ig. Akadémiai Kiadó, Budapest.

[8] Mike, G. (1940) Magyar Statisztikai Évkönyv IX. kötet, 1940. Pátria Irodalmi Vállalat és Nyomdai RT, Budapest.

[9] Szabó, L. (2005) A mezőgazdaság földrajza. Budapest: Szaktudás Kiadó.

[10] Bárdos, L., Husvéth, F. and Kovács, M. (2007) Gazdasági állatok anatómiájának és élettanának alapjai. Mezőgazda Kiadó, Budapest.

[11] Boadi, D., Benchaar, C., Chiquette, J. and Massé, D. (2004) Mitigation Strategies to Reduce Enteric Methane Emissions from Dairy Cows: Update Review. Canadian Journal of Animal Science, 84, 319-335. http://dx.doi.org/10.4141/A03-109

[12] Breazile, J.E. (1971) Textbook of Veterinary Physiology. Lea and Febriger, Philadelphia.

[13] Austin, C.J. (1981) Environmental Aspects of Housing for Animal production. Butterworths, London, Boston, Sydney, Wellington, Durban, Toronto.

[14] Ruckebusch, Y., Phaneuf, L.-P. and Dunlop, R. (1991) Physiology of small and large animals. B.C. Decker Inc., Philadelphia, Hamilton.

[15] Sjaastad, Ø.V., Sand, O. and Hove, K. (2010) Physiology of Domestic Animals. Scandinavian Veterinary Press, Oslo. 